\title{
Culture Medium and Varietal Selection for Establishment of Callus Culture of Artemisia annua
}

\author{
Chin Chee Keong ${ }^{1,2}$, Farah Alia Nordin², Arvind Bhatt ${ }^{2} \&$ Chan Lai Keng ${ }^{2}$ \\ ${ }^{1}$ Teacher Education Institute, Tuanku Bainun Campus, 14000 Bukit Mertajam, Penang \\ ${ }^{2}$ School of Biological Sciences, Universiti Sains Malaysia, 11800 Minden, Penang \\ ${ }^{1}$ Corresponding author: kevincck19@gmail.com
}

\begin{abstract}
Plant tissue culture technology offers the potential of producing medicinally important secondary metabolites such as anti-malarial artemisinin from Artemisia аппиа. In this study, callus induction of three different varieties of A.аппиа, namely T1, T2 and Hi varieties was carried out using leaf explants on Murashige \& Skoog (MS) and Litvay (LV) media with three different supplementations. MS medium added with $0.5 \mathrm{mg} / \mathrm{L} \mathrm{BA}, 0.5 \mathrm{mg} / \mathrm{L}$ NAA and $0.5 \mathrm{~g} / \mathrm{L}$ of casein hydrolysate $(\mathrm{CH})$ induced the highest yield of callus biomass compared to the effect of picloram- or 2,4-enriched MS medium. T2 variety was found to be the highest yielding variety in this medium. Picloram-enriched MS medium induced better callus in term of callus biomass and friability than 2,4-enriched medium. Hi variety induced in MS medium added with $0.5 \mathrm{mg} / \mathrm{L}$ picloram produced highest callus biomass among the three varieties. Callus formed on $0.5 \mathrm{mg} / \mathrm{L}$ picloram was also much more easily dispersed than callus of all three varieties cultured in the other two MS medium. LV-based medium was generally shown to be poor in inducing callogenic response from leaf explants. Therefore Hi callus sourced from MS medium supplemented with $0.5 \mathrm{mg} / \mathrm{L}$ picloram was selected to initiate liquid cell culture of $A$. апnиa which can further be explored for production of artemisinin, an anti-malarial compound.
\end{abstract}

Keywords: phytochemical, malaria, plant tissue culture

Abbreviations: MS - Murashige and Skoog's salts and vitamins [1]; LV - Litvay medium [2]; BA - 6benzyladenine; NAA - alpha-napthaleneacetic acid; 2,4-D - 2,4-dichlorophenoxyacetic acid; picloram - 4-amino-3,5,6-trichloropicolinic acid, $\mathrm{CH}$ - casein hydrolysate

\section{INTRODUCTION}

Artemisia annua L. is an aromatic Asteraceae plant species known as qinghao in China and thanh hao in Vietnam. A. апnиa is the only species which is able to synthesize artemisinin [3]. A. annua has gained interest due to anti-malarial compound, a sesquiterpene lactone, known as artemisinin. This compound is potent against chloroquine-resistant strains of Plasmodium falciparum as, the cause of cerebral malaria [4]. Artemisinin could be isolated from leaves, stems, buds, flowers and seeds of A. апnиа [5]. Although artemisinin-based drugs have been considered to be more effective for the malaria treatments, [6] reported that its low content in A. апnиa has made the use of artemisinin more costly than other drugs. Cultivation of A. аппиа is dependent on the seasonal and environmental limitations [3]. Besides this, the species shows variation in the amount of artemisinin content from different geographical origin due to genotypic variation, variation due to climatic and edaphic factors [7], source of plant tissue and time of harvesting [8]; [3]. Different stages of plant development also affects the artemisinin production. 
It is reported that leave possess highest artemisinin just before flowering [9]. Therefore it is important to search for alternative biotechnological methods to obtain higher production of artemisinin.

The aim of our study was to select suitable callus source for cell suspension culture from three different varieties of $A$. апnиa based on friability and biomass of callus induced on MS and LV media with three different supplementations.

\section{MATERIALS AND METHODS}

Aseptic plantlets of three varieties of A. аппиа (T1, T2 and Hi) maintained in MS medium [1] containing $30 \mathrm{~g} / \mathrm{L}$ sucrose, $7.8 \mathrm{~g} / \mathrm{L}$ agar were used in the present study. The plantlets of these three varieties were germinated from seeds obtained from the Institute of Tropical Biology, Vietnam.

Leaf explants $(0.3 \mathrm{~cm} \mathrm{X} 0.3 \mathrm{~cm})$ isolated from ten week-old plantlets were cultured on MS and LV medium were supplemented with (a) $0.5 \mathrm{mg} / \mathrm{L} \mathrm{BA}, 0.5 \mathrm{mg} / \mathrm{L} \mathrm{NAA}, 0.5 \mathrm{~g} / \mathrm{L} \mathrm{CH}$, (b) picloram (0, $0.5,1.0,1.5,2.0 \mathrm{mg} / \mathrm{L})$ and (c) 2,4-D (0, 0.5, 1.0, 1.5, $2.0 \mathrm{mg} / \mathrm{L})$. All media were added with $30 \mathrm{~g} / \mathrm{L}$ sucrose and $7.8 \mathrm{~g} / \mathrm{L}$ agar and medium $\mathrm{pH}$ was set between 5.7 to 5.8. All cultures were kept under 24hour cool white fluorescent light at $26^{\circ} \pm 1{ }^{\circ} \mathrm{C}$. Six replicates were used for each experiment. Statistical differences were analysed at $\alpha \leq 0.05$ by ANOVA followed with Tukey test (SPSS 12.0 for Windows).

\section{RESULTS}

\section{Effect of MS and LV media supplemented with BA, NAA and CH}

Both MS and LV medium enriched with $0.5 \mathrm{mg} / \mathrm{L} \mathrm{BA}, 0.5 \mathrm{mg} / \mathrm{L}$ NAA and $0.5 \mathrm{~g} / \mathrm{L} \mathrm{CH}$ could induce the callus from leaf explants in all the varieties of A. апnиа. However, MS medium enriched with 0.5 $\mathrm{mg} / \mathrm{L} \mathrm{BA}, 0.5 \mathrm{mg} / \mathrm{L} \mathrm{NAA}$ and $0.5 \mathrm{~g} / \mathrm{L} \mathrm{CH}$ medium produced significantly higher callus fresh weight in all the varieties (T1, T2 and Hi) as compared to that of LV-based medium. Among the three varieties, T2 variety was found to the best callus-yielding variety in MS medium with average fresh weight of $1.97 \pm 0.61 \mathrm{~g}$ as compared to $\mathrm{Hi}(0.99 \pm 0.22 \mathrm{~g})$ and $\mathrm{T} 1(0.42 \pm 0.11 \mathrm{~g})$ (Figure 1).

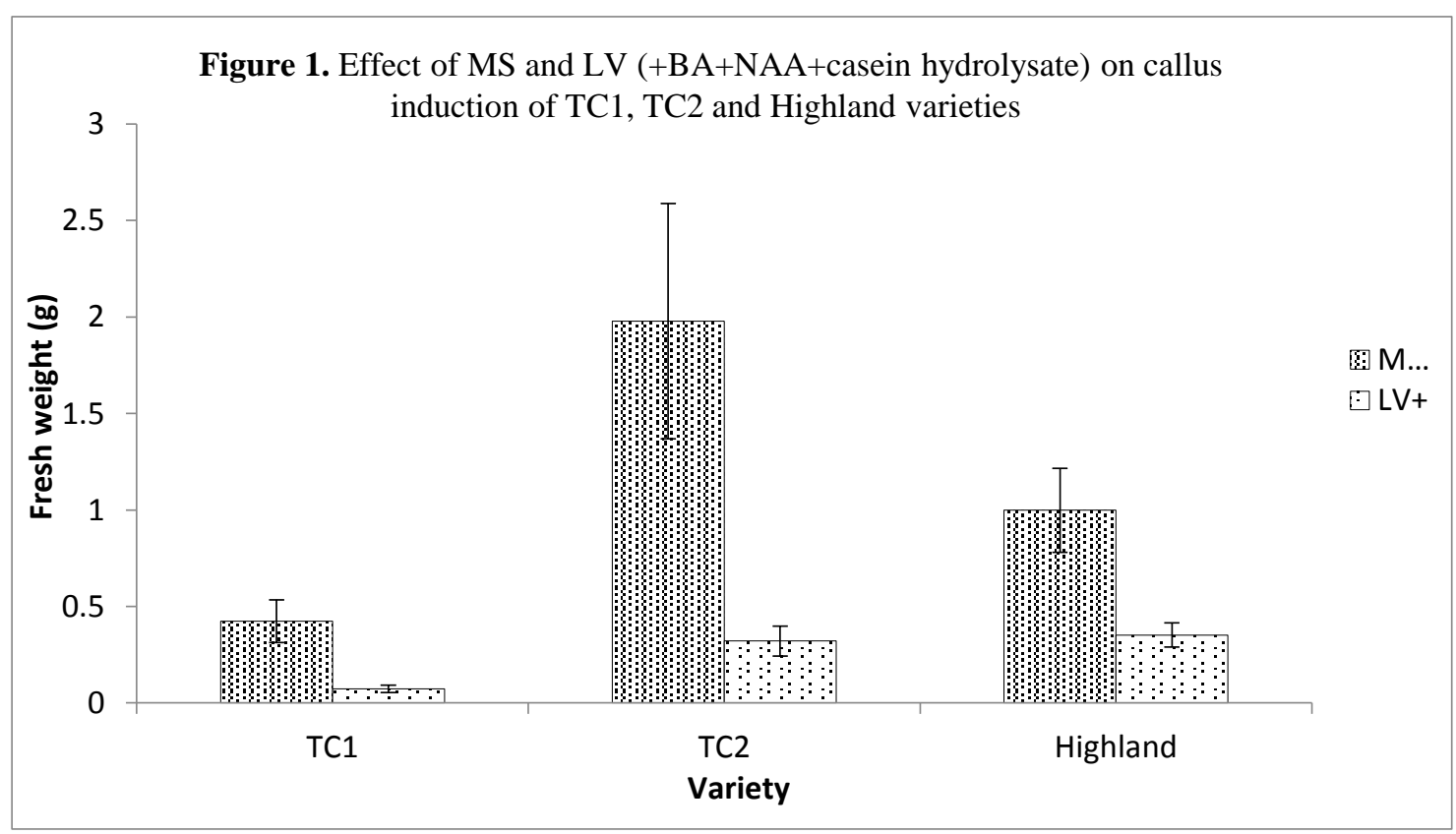


Results revealed that the callus produced by $\mathrm{T} 1$ variety was dark green in colour and semicompact in nature. However T2 variety produced light green, semi-compact callus (Plate 1a) whereas Hi variety produced green, semi-compact callus.

NAA has been commonly used with kinetin or BA for callus induction of A. annua [10]; [4]. In this study, the highest callus fresh weight $(1.97 \pm 0.61 \mathrm{~g})$ was produced by $\mathrm{T} 2$ variety in MS medium supplemented with BA, NAA and $\mathrm{CH}$. Different concentrations of $\mathrm{CH}$ was found to be effective to enhance the callus induction in other species i.e. indica rice genotype, MDU 5 [11], date palm [12] and deep water rice, Oryza sativa L. [13]. Use of case in hydrolysate in culture medium was also effective for callus proliferation in three different varieties of Rubus genus [14]. However in Oncidium (Gower Ramsey), $\mathrm{CH}$ was less effective for somatic embryogenesis as compared to the peptone as organic source of nitrogen in promoting embryo formation [15]. In the present study, $\mathrm{CH}$ may serve as an effective organic nitrogen supplement for increased callus yield in A. апnиа. It has been reported that $\mathrm{CH}$ is a source of 18 amino acids besides containing calcium and several micronutrients and vitamins [16]. The promotive effect of $\mathrm{CH}$ in callus induction was largely due to its rich source of amino acids and other unidentified growth-enhancing compounds.

\section{Effect of MS and LM media supplemented with picloram}

No callus induction was observed in control experiment (hormone-free medium) in all the varieties. The three varieties of A. annua showed different trend in callogenic response in MS and LV media supplemented with different concentrations of picloram. MS medium supplemented with picloram generally induced higher callus fresh weight as compared to LV-based medium. This result resembled callogenic response to $\mathrm{BA}, \mathrm{NAA}$ and $\mathrm{CH}$ supplementation.

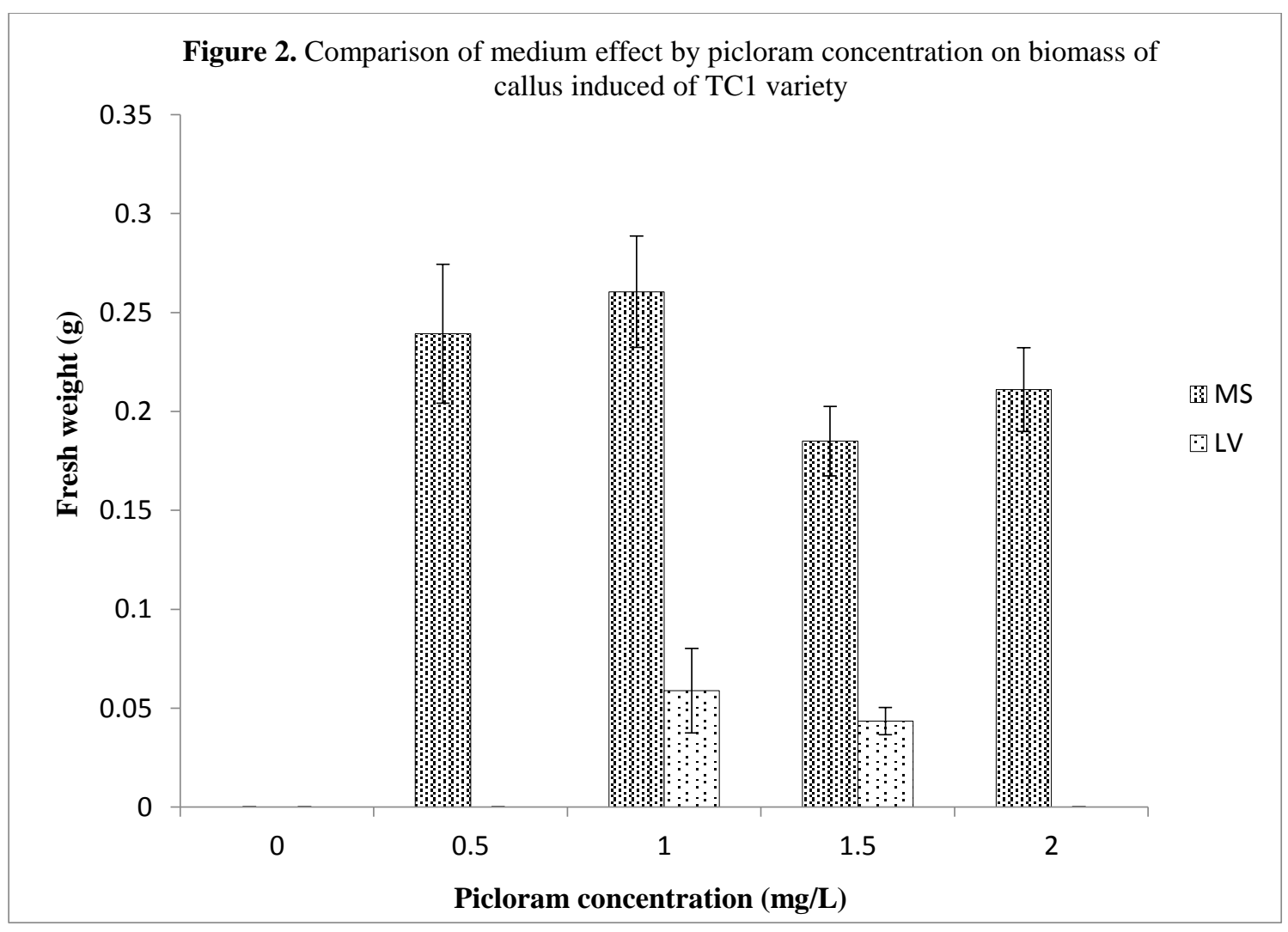


Figure 3. Comparison of medium effect by picloram concentration on biomass of callus induced of TC2 variety

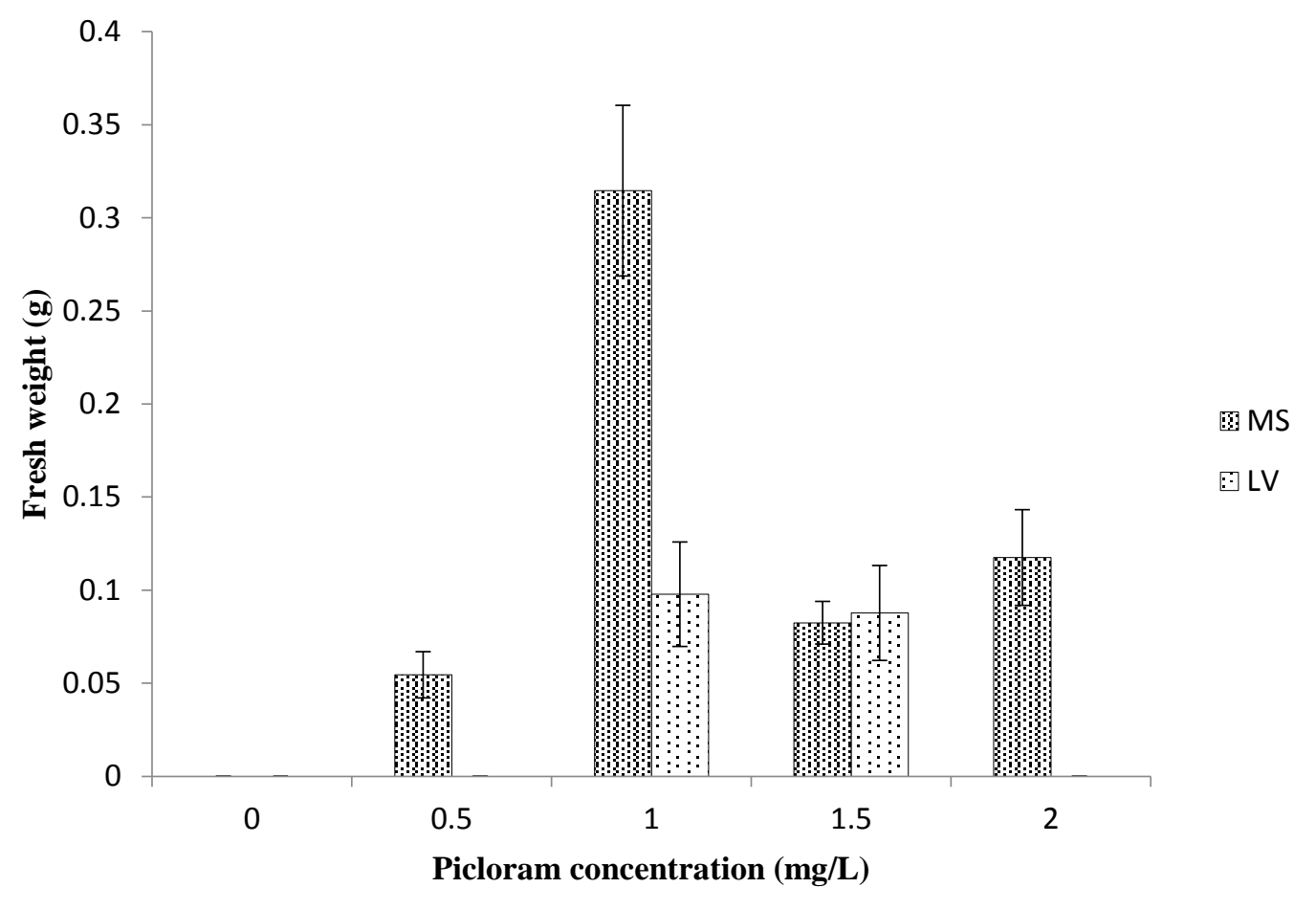

MS medium supplemented with picloram did not improve callus fresh weight of T1 variety (Figure 2). However in LV medium, callus induction occurred only in 1.0 and $1.5 \mathrm{mg} / \mathrm{L}$ picloram. As for T2 variety, MS medium enriched with $1.0 \mathrm{mg} / \mathrm{L}$ picloram produced significantly higher callus fresh weight $(0.31 \pm 0.09 \mathrm{~g})$ as compared to the other concentration of picloram (Figure 3$)$. T2 variety also showed callus induction only in LV medium supplemented with 1.0 and $1.5 \mathrm{mg} / \mathrm{L}$ picloram. MS medium supplemented with $0.5 \mathrm{mg} / \mathrm{L}$ picloram showed significantly highest callus fresh weight $(0.72$ $\pm 0.17 \mathrm{~g}$ ) as compared to the other concentration in Hi variety (Figure 4). Contrary to T1 and T2 varieties, $\mathrm{LV}$ medium enriched with different concentration of picloram ( 0.5 to $2.0 \mathrm{mg} / \mathrm{L})$ did induce some callus growth in Hi variety, albeit less than that induced in MS-based medium. 


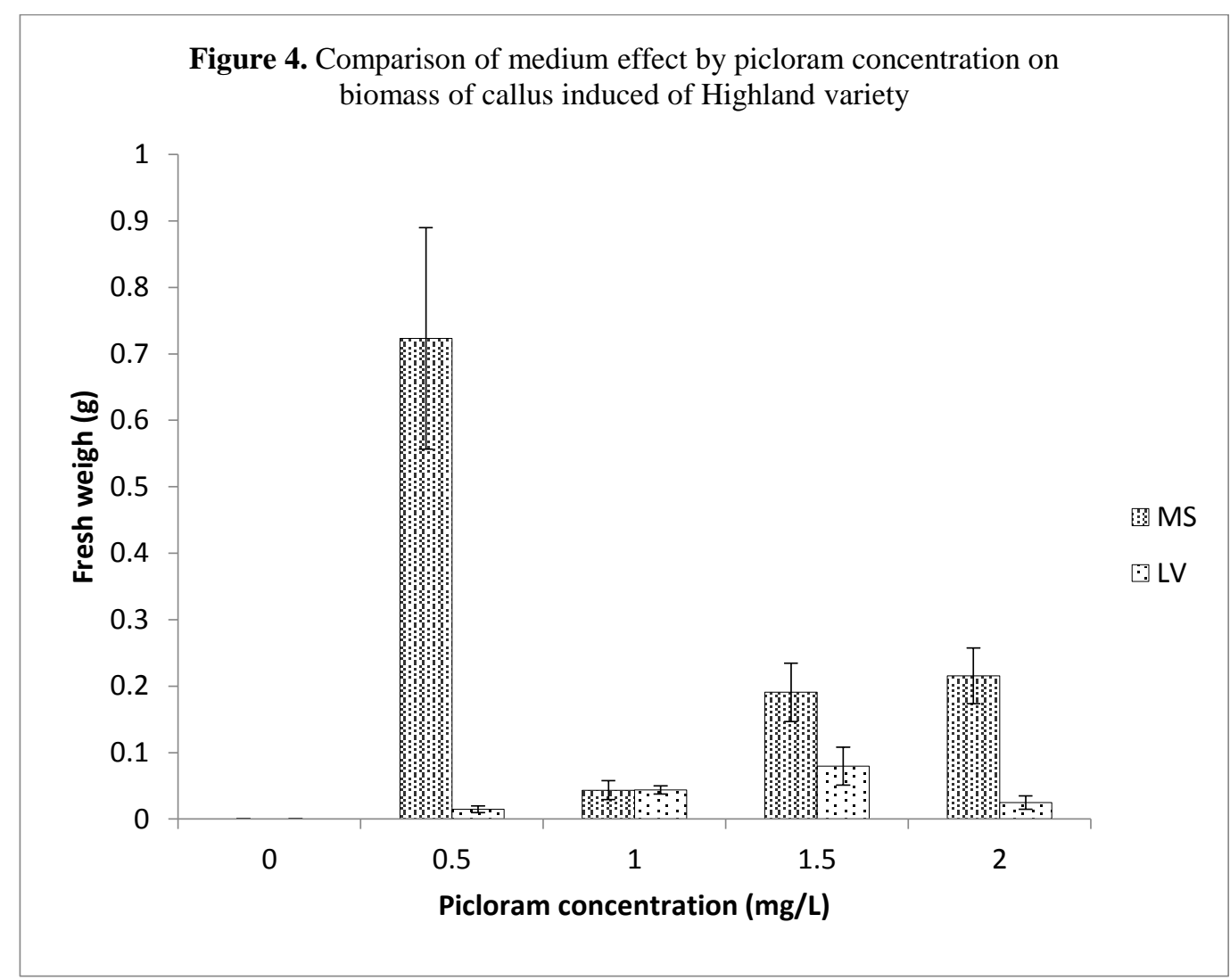

In this study, Hi variety showed the highest callus fresh weight $(0.72 \pm 0.17 \mathrm{~g})$ as compared to $\mathrm{T} 1(0.26 \pm 0.05 \mathrm{~g})$ and $\mathrm{T} 2(0.31 \pm 0.09 \mathrm{~g})$ varieties. Nallammai [17] reported similar findings in that MS medium enriched with $2.0 \mathrm{mg} / \mathrm{L}$ picloram produced soft and easily dispersed callus that weighed $0.78 \pm 0.25 \mathrm{~g}$ from leaf explants of $A$. аппиа (Europe origin). Callus produced by Hi variety were consistently friable and pale green in colour (Plate 1b). T1 variety produced pale green and semicompact callus in MS medium enriched with $0.5 \mathrm{mg} / \mathrm{L}$ picloram with $23.8 \%$ of the leaf explants showed root regeneration. However, MS medium enriched with $1.0 \mathrm{mg} / \mathrm{L}$ picloram produced hard and dark green colour callus (36.4\%) and pale green and friable callus $(63.4 \%)$ in T2 variety. Callus induced by all the varieties of A. аппиа in LV-based medium were either dark green or brown in colour with hard texture.

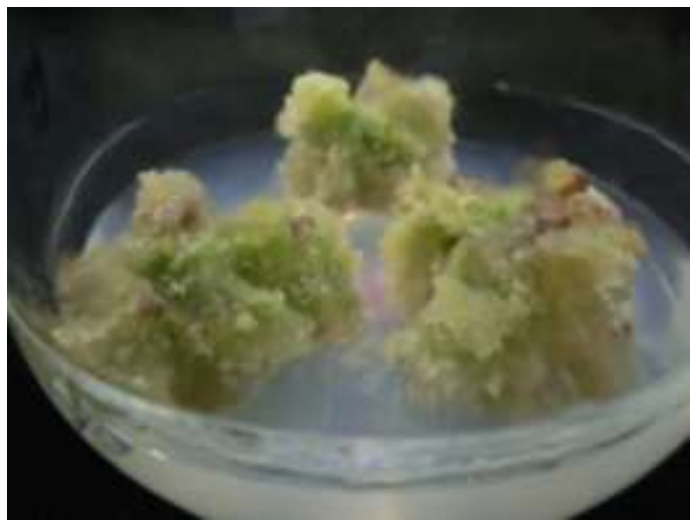

a

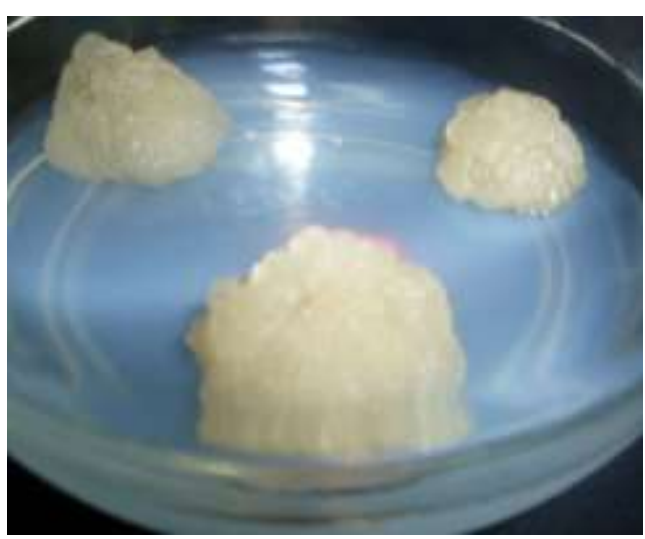

b

Plate 1 (a-b): Effect of medium composition on callus induction. (a) T2 callus on MS + 0.5 mg/L BA, 0.5 mg/L NAA and $0.5 \mathrm{~g} / \mathrm{L} \mathrm{CH}$. (b) Hi callus on MS $+0.5 \mathrm{mg} / \mathrm{L}$ picloram. 
Picloram had been shown to be the most effective growth hormones for callus induction of Rollina mucosa as compared to BA, NAA, 2,4-D and GA 3 [18]. Similarly, picloram was most suitable as a growth hormone for callus induction of Rubus strigosus as compared to 2, 4-D, NAA and zeatin [19]. It was reported to be an excellent auxin-like supplement to modified Gamborg B5 medium for callus growth of Taxus brevifolia. Picloram was found to provide better callus growth, for long-term subculturing, than other auxins tested [20]. Callus induction of Taxus x media var. Hatfieldii also benefitted from the use of picloram in culture medium [21].

\section{Effect of MS and LM media supplemented with 2,4-D}

The effect of 2,4-D in MS and LV media showed inconsistent result for all the three varieties of $A$. апnиа. Callus formed on 2,4-D-supplemented medium was poor in fresh weight and was visibly semicompact and brown in appearance. When MS-based medium was used, callus growth of T1 variety was observed in medium supplemented with $0.5,1.0,1.5 \mathrm{mg} / \mathrm{L} 2,4-\mathrm{D}$, whereas comparable callus growth occurred in LV-based medium supplemented with 1.5 and $2.0 \mathrm{mg} / \mathrm{L} \mathrm{2,4-D.} \mathrm{However,} \mathrm{no} \mathrm{callus}$ induction was found in MS medium supplemented with $2.0 \mathrm{mg} / \mathrm{L}$ picloram (Figure 5).

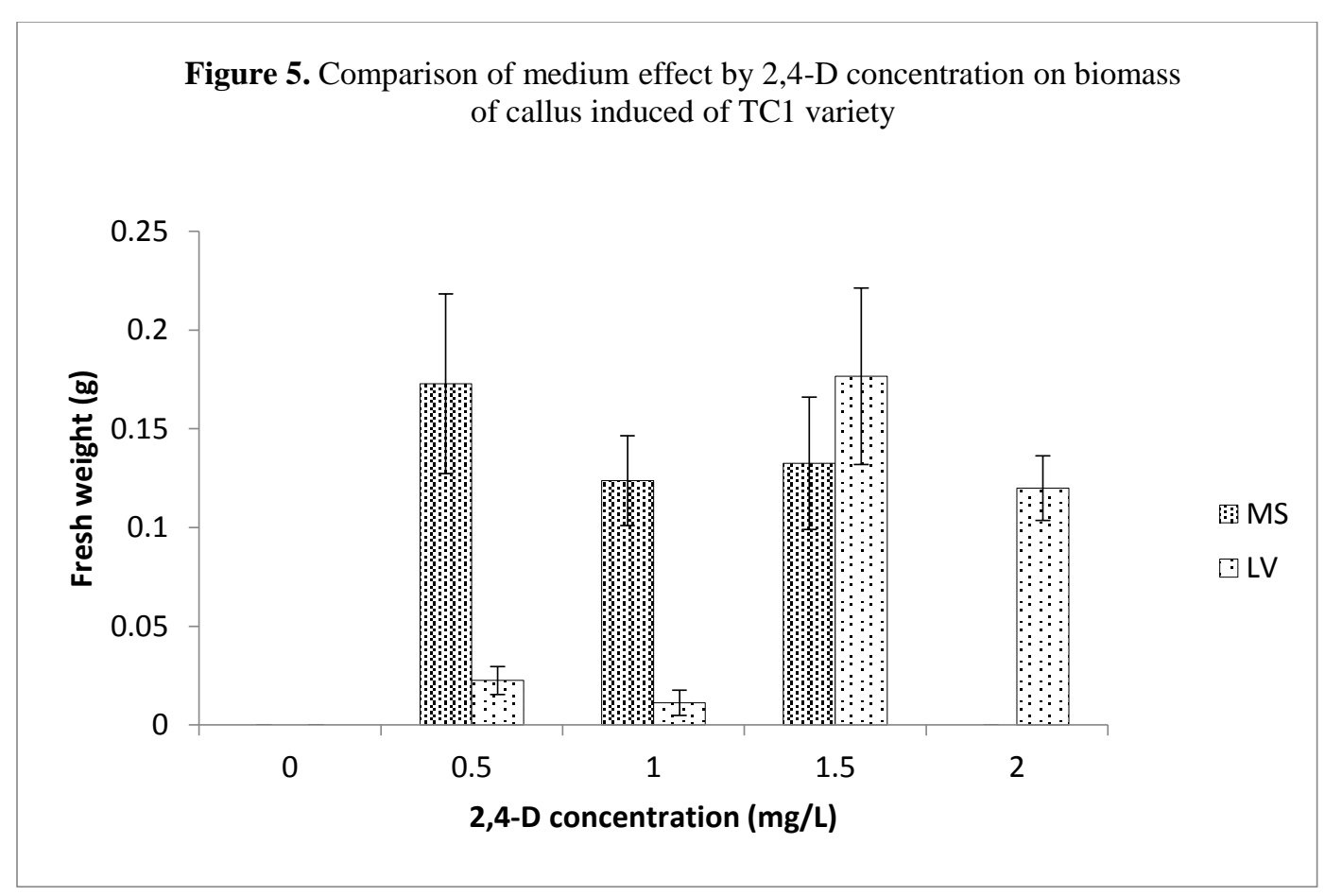




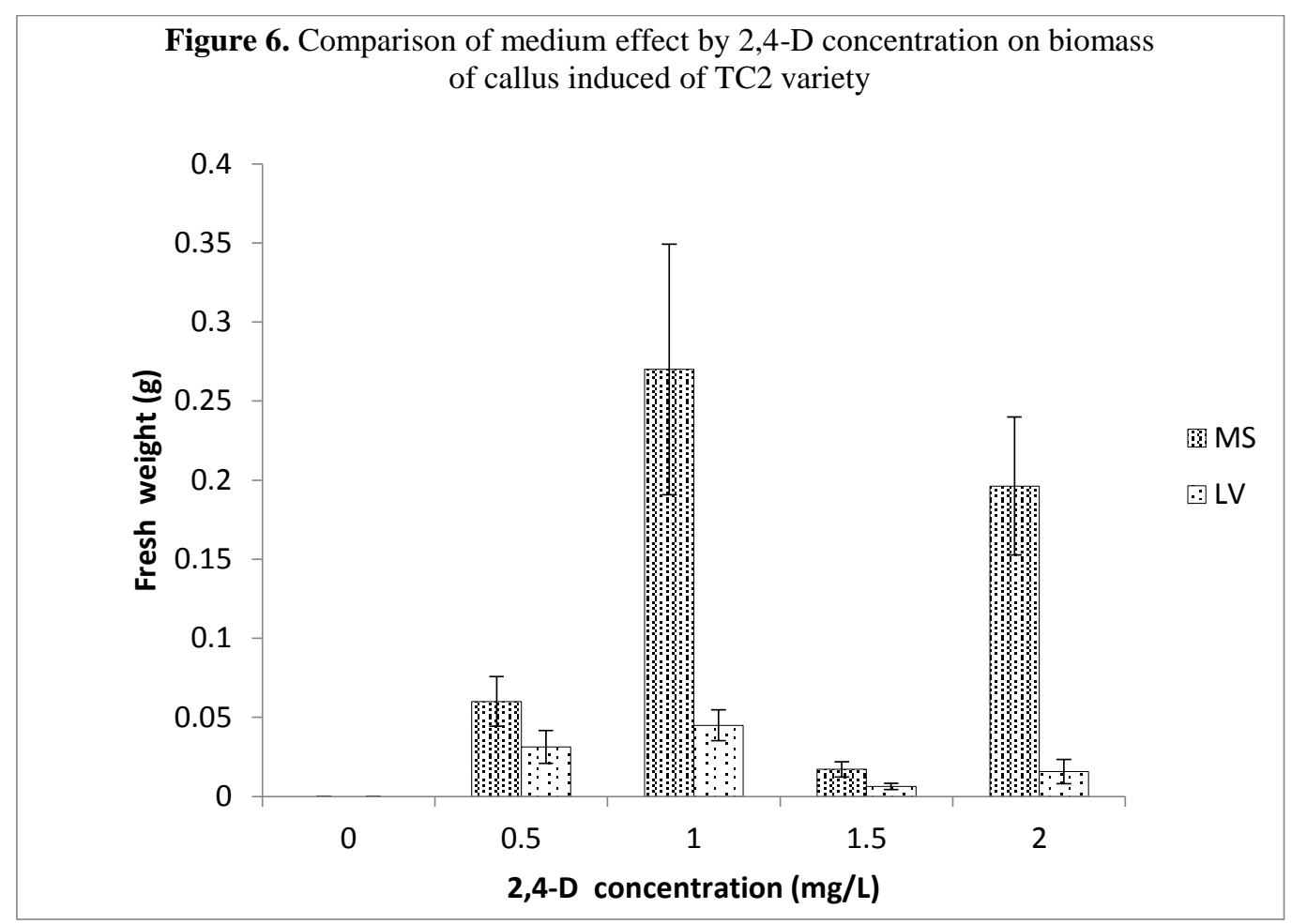

Callus growth of T2 variety was less than $0.05 \mathrm{~g}$ fresh weight in LV-based medium. High callus growth was recorded in MS medium enriched with 2,4-D at 1.0 and $2.0 \mathrm{mg} / \mathrm{L}$ concentrations, in which fresh weight was $0.27 \pm 0.08 \mathrm{~g}$ and $0.20 \pm 0.04 \mathrm{~g}$, respectively (Figure 6). Interestingly, LV-based medium enriched with 2,4-D supported callus induction of Hi variety. LV medium supplemented with $0.5 \mathrm{mg} / \mathrm{L} 2,4-\mathrm{D}(0.45 \pm 0.07 \mathrm{~g})$ and $1.5 \mathrm{mg} / \mathrm{L} \mathrm{2,4- \textrm {D }}(0.29 \pm 0.01 \mathrm{~g})$ produced significantly higher fresh weight of callus as compared to the other medium (Figure 7). This may suggest that addition of 2,4-D could compensate for the lack of nutrients content in LV medium. Contrarily callus induction was very poor in MS-based medium. 
Figure 7. Comparison of medium effect by 2,4-D concentration on biomass of callus induced of Highland variety

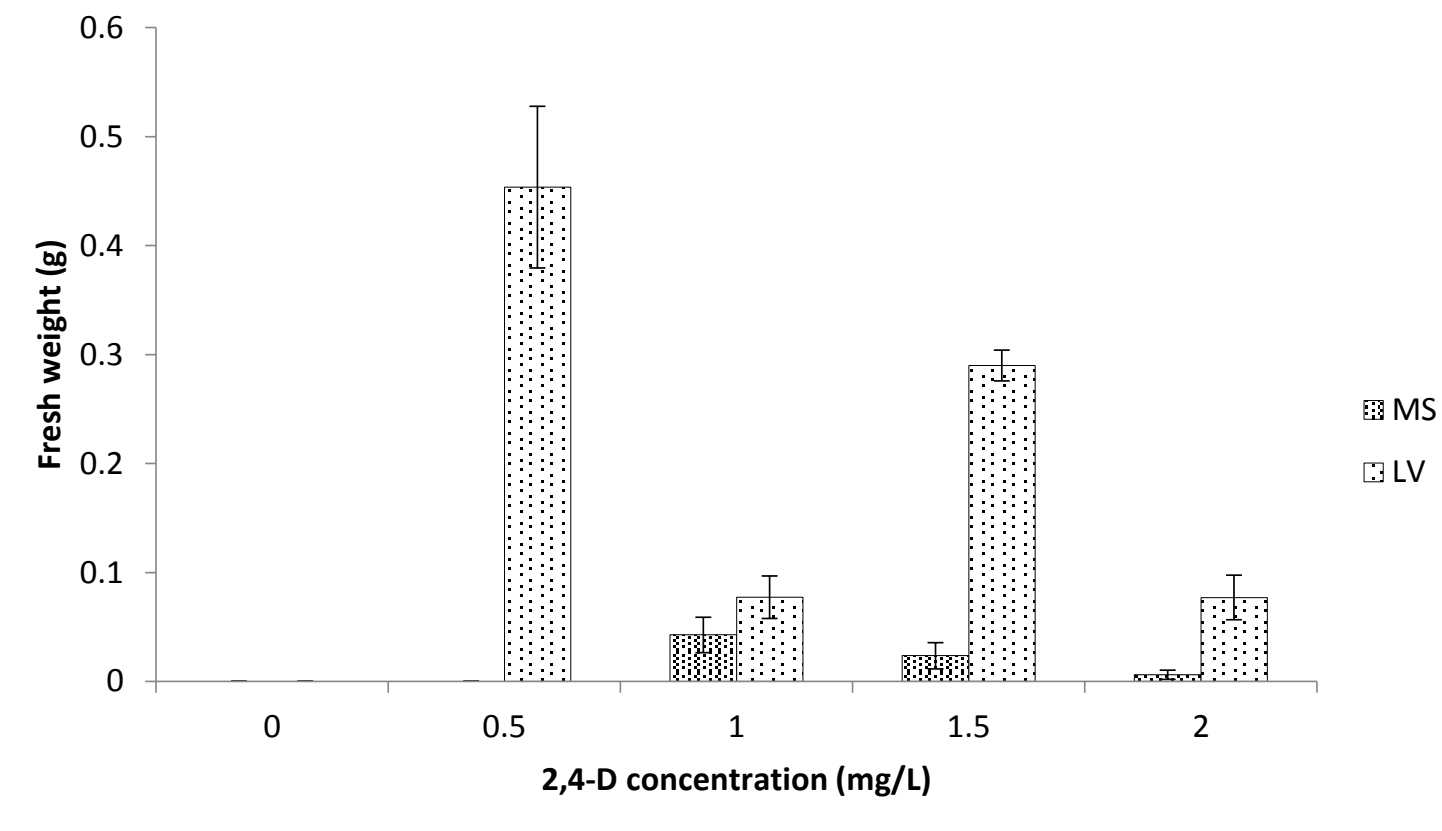

Other studies had shown that 2,4-D could prove to be an effective plant hormone for callus induction. As with NAA, 2,4-D has served as common plant growth regulators used together with kinetin for callus induction of A. аппиа [22].

\section{Comparison of MS and LV basal medium}

LV medium was originally formulated as conifer suspension medium based on analysis of chemical environment of archaegonium in immature Douglas-fir seed (Pseudotsuga menziesii) [2]. LV medium was used to maintain cell suspension and callus of both Douglas-fir (Pseudotsuga menziesii) as well as loblolly pine (Pinustaeda). Litvay [2] also reported that cereal species such as Avena sativa and Zea mays could grow better on LV than the MS medium. LV medium was also used for somatic embryogenesis in Picea sitchensis [23]. Since LV medium was developed for cell suspension of gymnosperm, it may not be suitable for maintaining A. аппиа callus, a herbaceous angiosperm. Our experiments to compare MS and LV as basal medium was prompted by personal communication with researchers from Institute of Tropical Biology in Vietnam who claimed that LV based medium was better than MS based medium for callus proliferation. We suspect that perhaps addition of certain supplements may yield such result, which in our case, happened not to be supplement of BA, NAA, CH or picloram. However, effect of 2,4-D supplement in LV medium for callus induction is worth further investigation.

\section{Varietal Differences}

Genotype-dependent variation of the plant tissue responses has been widely observed. It was found that Brassica oleracea var. gemmifera with different degree of embryogenic response produced differing amount of ethylene in anther culture [24]. Varietal effect was also observed in callus induction from 108 varieties of Oryza sativa L. [25] and five deep water rice varieties [13]. The present study revealed that different varieties of A. аппиа showed different response in terms of callus induction. Disparity in 
callus induction response of $\mathrm{T} 1, \mathrm{~T} 2$ and $\mathrm{Hi}$ varieties in three different medium supplementations may very well be due to interaction between genotypic variations and cultural composition.

\section{CONCLUSION}

Light colour callus with higher friability is considered to be more superior as compared to the compact callus with higher fresh weight. The results from this study indicated that Hi variety could produce light colour callus with high friability. Therefore, callus produced by Hi variety and MS medium enriched with picloram were selected as the source and medium for cell suspension culture picloram with the potential of in vitro production of artemisinin.

\section{REFERENCES}

[1] Murashige, T., \& Skoog, F. (1962). A revised medium for rapid growth and bioassays with tobacco tissue cultures. Physiologia Plantarum, 15: 473-497.

[2] Litvay, J.D., Johnson, M.A., Verma, D., Einspahr, D., \& Weyraunch, K. (1981). Conifer suspension culture medium development using analytical data from developing seeds. IPC Technical Paper Series Number 115.

[3] Baraldi, R., Issacchi, B., Predieri, S., Marconi, G., Vincieri, F.F., \& Bilia A.R. (2008). Distribution of artemisinin and bioactive flavonoids from Artemisia annua L. during plant growth. Biochemical Systematics and Ecology, 36, 340-348.

[4] Baldi, A., \& Dixit, V.K.(2008). Yield enhancement strategies for artemisinin production by suspension cultures of Artemisia annua. Bioresource Technology, 99: 4609-4614.

[5] Ferreira, J.R.S., Simon, J.E., \& Janick, J. (1995). Relationship of artemisinin content of tissue cultured, green house and field grown plants of Artemisia annua. Planta Medica, 61: 351-355.

[6] Liu, C., Zhao, Y., \& Wang, Y. (2006). Artemisinin: current state and perspectives for biotechnological production of an antimalarial drug. Applied Microbiology and Biotechnology, 72: 11-20.

[7] Vaz, A.P.A., Scaranari, C., Batista, L.A.R., Figueira, G.M., Sartoratto, A. \& Magalhaes, P.M. (2006.) Biomassa e composicaoquimica de genotiposmelhorados de especies medicinaiscultivadasemquatromunicipiospaulitas. Pesqui. Agropecu. Bras., 41, 869-872.

[8] Ferreira, J. F. S. \& Janick, J. (1995). Floral morphology of Artemisia annua with special reference to trichomes. International Journal of Plant Science, 156: 807-815.

[9] Namdeo, A.G., \& Mahadik, K.R., \& Kadam, S.S. (2006). Antimalarial Drug - Artemisia annua. Pharmacognosy Magazine, 2(6): 106- 111.

[10] Chenshu, A., Wang, X., Yuan, X., Zhao, B., \& Wang, Y.(2003). Optimization of cryopreservation of Artemisia annua L. callus. Biotechnology Letters, 25: 35-38.

[11] Zaidi, M.A., Narayanan, M., Sardana, R., Taga, I., Postel, S., Johns, R., McNulty, M., Mottiar, Y., Mao, J., Loit, E., \& Altosaar, I. (2006). Agronomy Research, 4(2): 563-575.

[12] Abdel-Rahim, E.A., Abdel-Fatah, O.M., El-Shemy, H.A., \& Abd El-Samei, M.B. (1998). Growth of date palm callus as affected by amino acids as organic nitrogen source. Arab Journal of Biotechnology, 1 (1), 99-106.

[13] Khaleda, L., \& Al-Forkan, M. (2006). Stimulatory effects of casein hydrolysate and proline in in vitro callus induction and plant regeneration from five deepwater rice (Oryza sativa L.). Biotechnology, 5(3): 379-384.

[14] Cantoni, L., Berardi, G., \& Rosati, P. (1993). ISHS ActaHorticulturae 352: VI International Symposium on Rubus and Ribes.

[15] Chen, J.T., \& Chang, W.C. (2002). Effects of tissue culture condition and explant characteristics on direct somatic embryogenesis in Oncidium 'Gower Ramsey'. Plant Cell, Tissue and Organ Culture 69; 41-44.

[16] Inoue, M., Maeda, E. (1982). Control of organ formation rice callus using two-step culture method. In A. Fujiwara (Ed.), Plant tissue culture (pp. 183-184). Tokyo: Maruzen.

[17] Nallammai, S. (2005). Preparation of cell suspension culture of Artemisia annua L. for the production of artemisinin. Ph.D. Thesis, Sch. Biol. Sc., Univerisiti Sains Malaysia, Malaysia. 
[18] Figueiredo, S. F. L., Simoes, C., Albarello, N. \&Viana, V. R. C. (2000). Rollina mucosa cell suspension cultures: Establishment and growth conditions. Plant Cell, Tissue and Organ Culture, 63: 85-92.

[19] Hollmann, P.J., Lohbrunner, G.K., Shamoun, S.F., \& Lee, S.P. (2002) Establishment and characterization of Rubus tissue culture systems for in vitro bioassays against phytotoxins from Rubus fungal pathogens. Plant Cell, Tissue and Organ Culture, 68 43-48.

[20] Ketchum, R.E.B., Gibson, D.M. \& Greenspan, G.K. (1995). Media optimization for maximum biomass production in cell cultures of pacific yew. Plant Cell, Tissue and Organ Culture, 42: 185-193.

[21] Furmanowa, M., Glowniak, K., Syklowska-Baranek, K., Egorka, G., \& Jozefczyk, A. (1997). Effect of picloram and methyl jasmonate on growth and taxane accumulation in callus culture of Taxus $\times$ media var. Hatfieldii. Plant Cell, Tissue and Organ Culture. 49: 75-79.

[22] Paniego, N.B., \& Giulietti, A.M. (1994). Artemisia аппиа L.: dedifferentiated and differentiated cultures. Plant Cell, Tissue and Organ Culture, 36: 163-168.

[23] Ingram, B., \& Mavituna, F. (2000). Effect of bioreactor configuration on the growth and maturation of Piceasitchensis somatic embryo cultures. Plant cell, tissue and organ culture, 61: 87-96.

[24] Biddington, N.L., \& Robinson, H.T. (1991). Ethylene production during anther culture of Brussels sprouts (Brassica oleracea var. gemmifera) and its relationship with factors that affect embryo production. Plant Cell, Tissue and Organ Culture, 25: 169-177.

[25] Mikami, T., \& Kinoshita, T. (1988). Genotypic effects on the callus formation from different explants of rice, Oryzasativa L. Plant Cell, Tissue and Organ Culture, 12: 311-314. 